\title{
Exploring Social Enterprises' Innovation Capabilities in Malaysia: A Qualitative Study
}

\author{
${ }^{1}$ E. S. Kassim and T. A. Mohd Tajmi \\ Faculty of Business and Management, Universiti Teknologi MARA \\ 42300 Puncak Alam, Selangor, MALAYSIA
}

\begin{abstract}
This paper explores the social enterprise (SE) innovation capabilities for driving the achievement of social orientation. SE is vital as the third sector economy that addresses on the social, economic and environment agenda. Studying the phenomena of social entrepreneurship and explaining the social enterprises' unique behaviors, characteristics, and typologies will advance research for creating sustainable public wealth. Using the qualitative study method, we propose product/service innovation, process innovation, management innovation and marketing management as the model in driving for social enterprise to achieve their social impacts. The model offers an opportunity for evaluation and validation via other research technique. Ultimately, it could be used to steer more research agenda and contribute to social enterprises sustainability as the third sector economy.
\end{abstract}

Keywords: Social enterprise, social enterprise innovation capability, antecedents of social enterprise success, social enterprise impacts

\section{Introduction}

In all parts of the world, we are witnessing a remarkable growth of the third sector economy, which is defined as the socio-economic initiatives which belong neither to traditional private for profits sector nor to the public sector (Defourny \& Borzaga, 2001). Social enterprise is the backbone of the third sector that involves business as an instrument for social development, which is established with the main agenda of creating positive social change and social values. Xolani (2012) emphasized on the Organisation for Economic Co-operation and Development (OECD) definition that describes SE activities, which are conducted privately, but for the benefits of public interests. Hence, in comparison to business functions, SE focuses more on how the activities could create positive impacts to the society (Umberto, Lisa \& Berger, 2015). The impacts could be to the health and wellbeing improvement, better access to education and housing, environment and sustainability, or in the provision of stable and quality employment (Caroline and Antonio, 2011).

However, maintaining a social enterprise establishment is very challenging. Running the enterprise as a voluntary organization, with limited funds and complex governance relationships requires dynamic strategies for its success continuance. As social enterprises are reflected as private activities conducted in and with public interest (Xolani, 2014), which seek to serve the community's interest rather than profit maximization (Umberto, Lange \& Berger, 2015), the social enterprise's innovation capability and ability to sustain funds are essential. Therefore, in this paper, we explore how innovation capabilities are essential in driving towards social orientation achievements. 


\section{Review of Literature}

\subsection{Social Enterprise}

Social entrepreneurship was introduced in the 1970s to address the issue of social problems sustainably (El Ebrashi, 2013). It was first mentioned in 1972 by Joseph Banks in his seminal work named The Sociology of Social Movements. Since then, social enterprise have been used extensively to define works related to "process involving the innovative use and combination of resources to pursue opportunities to catalyse social change and/or address social needs" (Hausmann, 2015). Although there are different types of social enterprises, (Milligan, 2013) outlined SE based on profit/nonprofit-orientation and sources of funds which draw into three major categories; 1) Leveraged non-profits, 2) Hybrid non-profit ventures and 3) Social business ventures.

As SE agenda mainly focuses on social and economic development, and improving the quality of life, the most efficient way to promote innovation in social enterprises is by ensuring systematic social impact as well as an economic return. Social enterprise could be explained from the perspective of systems or stakeholder theory. Similarly, it could be conceptualized based on social ecology theory, which describes the interrelations of social, economic and environment constituents that interact and form the reconstructive ecological approach to society (Bookchin, 1974). Likewise, the performance could be evaluated from the aspects of three characteristics of triple-bottom line, which are economic, social and environment (Elkington, 1998). The economic bottom line deals with the economic benefits enjoyed by the host society, the social bottom line is the social equity that pertains to fair and beneficial business practices and the environment ecology are the benefits to the natural capital.

\subsection{Innovation Strategy and Dynamic Capability}

The role of social entrepreneurs in the third sector economy is very challenging. Leveraging social networks, assembling resources and bridging institutional voids (Gupta, Beninger \& Ganesh, 2015) require collective actions and continuous innovative strategies. Without an innovation strategy, innovation improvement efforts can easily become "a grab bag of much-touted best practices" (Pisano, 2015). Looking at the nature of social enterprise, four characteristics of innovation strategies are fundamental. These are service/product innovation, process innovation, management innovation and marketing innovation.

\subsubsection{Product/Service Innovation Strategy and SE Performance}

Product or service innovations are the introduction of a new creation to meet an external user or the market needs (Damanpour \& Aravind, 2012). While research on product/service innovations often focus on large and medium size organizations, effort has been made by (Verhees \& Meulenberg, 2004) to examine the effects of product innovation to small enterprises' performance. The results indicate innovativeness has a strong influence to performance. Recent findings also conclude product innovation is the determinant of organizational performance (Jajja, Kannan, Brah \& Hassan, 2017). Hence, product/service innovations should be regarded as important criteria in sustaining social enterprise.

\subsubsection{Process Innovation Strategy and SE Performance}

Viewing innovation as a process means addressing "how" rather than "what" or "how many" (Crossan \& Apaydin, 2010). It could be categorised based on levels of analysis, internal, and external drivers. Viewing the levels of analysis, process innovation can be examined at the levels of individual, 
group, organizational, and at the population or inter-organization. Next, the internal drivers include direction, which relates to top-down versus bottom-up processes; source or inspiration for ideas stemming from internal, external and locus, which refers to space of innovation such as closed (within firm) versus open (or networked) processes. Finally, the external drivers can include influences stemming from markets or regulation (Crossan \& Apaydin, 2010).

Rousseau, Mathias, Madden and Crook (2016), concluded the integration of both product and process innovations yield stronger performance gains. Thus, process innovation should be included as an important determinant of SE performance.

\subsubsection{Management Innovation Strategy and SE Performance}

Management innovation is a form of process innovation that is considered non-technological and influential in impacting success measures (Černe, Jaklič \& Škerlavaj, 2013). Based on (Damanpour, \& Aravind, 2012), management innovation encompasses processes that lead to change in strategy, structure, administrative processes, and systems. It positions managerial innovation as new organizational structures, administrative systems, management practices, processes and techniques that could create value for the organization, and is considered very important. In the context of social enterprise, having good relationships with multi stakeholders is the key to success. Kim and Moon (2017) concluded managerial capacity is an antecedent of social enterprise performance. Hence, community relationship, relationship governance and partner selection must be addressed adequately.

\subsubsection{Marketing Innovation Strategy and SE Performance}

Marketing strategy is the initiative that dwells into the branding, low-cost and channel strategy (Hsu, 2011). From this perspective, marketing strategy and product innovation are closely linked. Even though the marketing innovation strategy was not extensively studied in social enterprise research, Liu, Eng and Takeda (2015) found the evidences that marketing capabilities and marketing orientation predict both social and economic performances of social enterprises. Therefore, it is crucial to address the marketing strategies appropriately for sustaining the social involvement.

\section{Method}

\subsection{Research Method and Design}

Since the aim of the research is to gain insights and capture the richness of the key issues and challenges, a case study using the interview as a technique for data collection was conducted. The method is believed to provide empirical inquiries that investigate the contemporary phenomenon. Furthermore, the purpose and focus of the method is to describe the meaning, provide deep understanding, and interpretation of the textual information derived from the interviews, hence clariying ways of thinking in relation to certain phenomenon (Johannessen, 1997). Yin (2003) claimed interviews are esstial part of the case study evidence. In order to gain a holistic comprehension and reflection, the interviews were conducted with the founders of the social enterprises. Semi-structured interviews were conducted that allows for probing the answers for more input. Robson (2002) mentioned semi-structured interviews allow for flexibility in which omission or addition of questions during the interview is common. In similar context, Yin (2003) referred the semi-structured interview as the semi-structured focused interview.

Even though the aim of the study was to get insights of how innovation capabilities are essential, we started by asking general questions, followed by specific queries. [Kruger \& Casey, 2000] suggest 


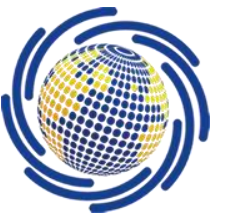

8th International Conference on Modern Research in

Management, Economics and Accounting

October 19-21, 2018 / Munich - Germany

using questions that can get participants to involve and the questions should be focused. Probing of the answers followed subsequently. Thus, following the suggestion, two main questions were prepared;

1. What are are you trying to achieve?

2. How do you drive your enterprise's achievements?

\subsection{Identification of Informants}

In determining the appropriate number of cases for the study, suggestions by Yin (2003) are followed. According to Yin (2003), a case study use an empirical enquiry that rises out of the need to understand complex phenomenon, within a real-life context, by undertaking in-depth data collection involving multiple sources of information. The keyword is replication. In similar view, Corbin and Strauss (1990) emphasized on the importance of achieving representativeness and consistency. It is however, the representativeness is not on the persons, rather it is the concept of the study. Therefore, a decision was made to cease the data collection once there are evidences for replicated results. In this study, a total of six social enterprise founders took part as the research informants. As social enterprise is just recently blooming in Malaysia, all of these enterprises are considered very young. All of them were in the same maturity cohort which is less than 5 years in operation. In addition, all of the enterprises obtained some supports and assistance from a third party. Hence, they were in the homogeneous group with identical business characters.

\subsection{Data gathering and analysis}

Based on the recommendation from Corbin and Strauss (1990), the interview responses were reviewed and written up by sentences or paragraphs. Then, each sentence and paragraph was first assigned with low-level labels. Next, the low-level labels were re-categorised into medium-level labels. Finally, the medium-level labels were matched against high-level themes. This technique is parallel with the open coding, axial coding and selective coding procedure (Corbin and Strauss, 1990; Attride-Stirling, 2001).

In this study, generation of the social orientation higher-level themes was derived from the Triple Bottom Line theory of social, economic and environment assessment. On the other hand, generation of the innovation capabilities was derived from the dynamic capability theory and innovation strategy, which are product/service innovation, process innovation, management innovation and marketing innovation.

\section{Findings and Discussion}

\subsection{Social Orientation: Mission, Performance and Impacts}

Analysing the interview reports and using the constant comparison approach, feedback from the social enterprises reflecting on their social mission, performance and impacts is shown in Table 1.

Table 1: The Social Enterprises' Social Orientation

\begin{tabular}{l|l|l} 
Social & Business Focus & Social Orientation (Social mission, performance and impacts)
\end{tabular}




\begin{tabular}{|c|c|c|c|c|}
\hline \multicolumn{2}{|l|}{$\begin{array}{l}\text { Enterprise } \\
\text { (SE) }\end{array}$} & Social & Economy & Environment \\
\hline SE1 & $\begin{array}{l}\text { Solution provider for } \\
\text { clean water to the } \\
\text { indigenous groups }\end{array}$ & $\begin{array}{l}\text { - Community problem } \\
\text { solutions, quality of } \\
\text { life, provision of clean } \\
\text { water }\end{array}$ & $\begin{array}{l}\text { - Cost effective } \\
\text { solutions }\end{array}$ & $\begin{array}{l}\text { Non-toxic } \\
\text { solutions with } \\
\text { the reduction of } \\
\text { electricity } \\
\text { dependency, }\end{array}$ \\
\hline SE2 & $\begin{array}{l}\text { Human capital } \\
\text { quality training for } \\
\text { low income groups }\end{array}$ & $\begin{array}{l}\text { - Social quality } \\
\text { - }\end{array}$ & $\begin{array}{l}\text { - Income generation for } \\
\text { the groups - }\end{array}$ & $\begin{array}{c}\text { Reduction of } \\
\text { carbon emission }\end{array}$ \\
\hline SE3 & $\begin{array}{l}\text { Peer-to peer car } \\
\text { sharing and rental, }\end{array}$ & - "We culture" & $\begin{array}{l}\text { - Sharing economy } \\
\text { - value creation of }\end{array}$ & $\begin{array}{c}\text { Reduction of } \\
\text { carbon footprint }\end{array}$ \\
\hline \multirow{3}{*}{$\begin{array}{c}\text { Social } \\
\text { Enterprise } \\
\text { (SE) }\end{array}$} & Business Focus & \multicolumn{3}{|c|}{ Social Orientation (Social mission, performance and impacts) } \\
\hline & & Social & Economy & Environment \\
\hline & utilizing on idle cars & & microenterprise & \\
\hline SE4 & $\begin{array}{l}\text { On the go car } \\
\text { maintenance service }\end{array}$ & $\begin{array}{l}\text { - Social: improving } \\
\text { quality of life, } \\
\text { community } \\
\text { development }\end{array}$ & $\begin{array}{l}\text { - Sharing economy } \\
\text { - value creation of } \\
\text { microenterprise }\end{array}$ & $\begin{array}{c}\text { - } \\
\text { Reduction of } \\
\text { carbon footprint }\end{array}$ \\
\hline SE5 & $\begin{array}{l}\text { Transparent crowd } \\
\text { funding for less } \\
\text { privileged groups in } \\
\text { furthering their } \\
\text { education }\end{array}$ & $\begin{array}{l}\text { - Improving quality of } \\
\text { life } \\
\text { - Access to education and } \\
\text { knowledge } \\
\text { - Social return on } \\
\text { investment (SROI) } \\
\text { - }\end{array}$ & $\begin{array}{c}\text { - Socio-economic } \\
\text { improvement }\end{array}$ & $\begin{array}{l}\text { - No specific } \\
\text { environment } \\
\text { mission }\end{array}$ \\
\hline SE6 & $\begin{array}{l}\text { Reengineer the food } \\
\text { supply-chain }\end{array}$ & - Social inclusion & $\begin{array}{l}\text { - Sharing economy } \\
\text { - Value creation of } \\
\text { microenterprise }\end{array}$ & $\begin{array}{cc}\text { Reduction of } \\
\text { carbon footprint }\end{array}$ \\
\hline
\end{tabular}

Referring to the respondents' social orientation, there is one common theme which fulfilling the social, economic and environment value creation is the aim. Regardless of the business focus, social integration, inclusion, quality of life and sharing economy have become their key performance indicators. In fact, they take the social orientation very seriously by conducting periodic evaluation and assessment.

\subsection{Social Enterprise Innovation Capabilities}

This section explains the innovation capabilities, which are essential for achieving social enterprise's social orientation. The capabilities are classified in higher-order groupings that describe the main innovation strategy: product/service, process, management and marketing innovation. Figure 1 illustrates the major findings of the analysis. Reflecting on the findings in Figure 1, there are evidences for how innovation capabilities are essential in driving towards social orientation achievement. Building from the essence of product/service innovation, process innovation, management innovation and marketing innovation, each theme proposes for unique capabilities. 
First, the innovativeness of the social enterprises product/services are explained by their abilities to offer emerging products which are cost effective and meet the peoples' needs. The products offered are based on lean innovation and the services utilise the communication technology, which aligns with the society and consumer lifestyles. In addition, there is flexibility for product scale up should the needs arise. Furthermore, the products/services are also cost effective. The idea of utilizing idle resources and shared resources with personal social touch allows anyone to participate as part of the social enterprise ecosystem. Finally, the solutions offered are for reducing the people issues. Cost of living, household income, access to education and financial independence are some of the common challenges that require social attention. Therefore, by focusing on the solutions to the problems, it creates creativity that allows for unique ideas.

Second, agile business model, sharing economy process-based and competencies are playing their roles in explaining for process innovation success. As social enterprise is operated from the people for the people, the ability to react to stakeholders' needs is very important. Therefore being sensitive to the surrounding will help. This can be achieved by conducting periodic assessment that measures their social orientation impacts. In addition, the social enterprise must also be able to innovate for self-sustaining the business. Two of the strategies are to be creative in designing a value creation process, which allows for more social participation and integration and open for cross-selling system.

Figure 1: Model of Social Enterprise Innovation Capabilities

\begin{tabular}{|c|c|c|c|c|c|c|}
\hline $\begin{array}{c}\text { THEME/ } \\
\text { GROUPING }\end{array}$ & \multicolumn{3}{|c|}{ SERVICE/PRODUCT } & \multicolumn{2}{|r|}{ PROCESS } & \\
\hline Categories & $\begin{array}{l}\text { Emerging } \\
\text { Product/ } \\
\text { Services }\end{array}$ & $\begin{array}{c}\text { Cost } \\
\text { Effective }\end{array}$ & $\begin{array}{c}\text { People issue } \\
\text { solution }\end{array}$ & $\begin{array}{c}\text { Agile } \\
\text { business } \\
\text { model }\end{array}$ & $\begin{array}{l}\text { Sharing } \\
\text { economy }\end{array}$ & Competencies \\
\hline \multirow{6}{*}{ Example } & $\begin{array}{c}\text { Lean } \\
\text { innovation }\end{array}$ & $\begin{array}{c}\text { Maximum } \\
\text { utilization of } \\
\text { idle resources }\end{array}$ & $\begin{array}{c}\text { Reducing cost } \\
\text { of living }\end{array}$ & $\begin{array}{l}\text { Resource } \\
\text { leverage }\end{array}$ & $\begin{array}{l}\text { Community } \\
\text { ownership }\end{array}$ & Digital abilities \\
\hline & $\begin{array}{l}\text { Technology } \\
\text { oriented }\end{array}$ & $\begin{array}{c}\text { Shared } \\
\text { ownership }\end{array}$ & $\begin{array}{c}\text { Improving } \\
\text { household } \\
\text { income }\end{array}$ & $\begin{array}{l}\text { Stakeholder } \\
\text { reaction }\end{array}$ & $\begin{array}{l}\text { Demand and } \\
\text { supply } \\
\text { reengineering }\end{array}$ & $\begin{array}{c}\text { Assests } \\
\text { reconfiguration } \\
\text { capabilities }\end{array}$ \\
\hline & \multirow[t]{4}{*}{$\begin{array}{l}\text { Scale-up } \\
\text { solutions }\end{array}$} & \multirow[t]{4}{*}{ Social touch } & $\begin{array}{c}\text { Better aceess to } \\
\text { education }\end{array}$ & $\begin{array}{c}\text { Periodic } \\
\text { assessment \& } \\
\text { monitoring }\end{array}$ & $\begin{array}{l}\text { Peer-to-peer } \\
\text { engagement }\end{array}$ & Personal "touch" \\
\hline & & & $\begin{array}{c}\text { Skill } \\
\text { development }\end{array}$ & \multirow[t]{3}{*}{$\begin{array}{l}\text { Solution } \\
\text { integration }\end{array}$} & $\begin{array}{l}\text { Value chain } \\
\text { creation }\end{array}$ & \multirow[t]{3}{*}{$\begin{array}{c}\text { Self-sustainable } \\
\text { ability }\end{array}$} \\
\hline & & & $\begin{array}{c}\text { Financial } \\
\text { independence }\end{array}$ & & \multirow[t]{2}{*}{ Cross-selling } & \\
\hline & & & $\begin{array}{c}\text { Access to basic } \\
\text { needs }\end{array}$ & & & \\
\hline \multirow{4}{*}{ Example } & \multirow[b]{2}{*}{ Resilience } & \multirow[b]{2}{*}{$\begin{array}{c}\text { Sustainable } \\
\text { plan }\end{array}$} & \multirow{2}{*}{$\begin{array}{l}\text { Talent \& } \\
\text { capacity } \\
\text { building }\end{array}$} & \multirow{2}{*}{$\begin{array}{l}\text { Government } \\
\text { and authority } \\
\text { involvement }\end{array}$} & $\begin{array}{l}\text { Awareness } \\
\text { creation }\end{array}$ & \multirow[b]{2}{*}{ Market tapping } \\
\hline & & & & & $\begin{array}{c}\text { Compassion } \\
\text { creation }\end{array}$ & \\
\hline & $\begin{array}{c}\text { Forward thinking } \\
\text { culture }\end{array}$ & $\begin{array}{c}\text { Strategic } \\
\text { investment }\end{array}$ & $\begin{array}{l}\text { Core value } \\
\text { creation }\end{array}$ & $\begin{array}{l}\text { Incubator } \\
\text { participation }\end{array}$ & Crowdfunding & $\begin{array}{c}\text { Partnership \& } \\
\text { strategic alliance }\end{array}$ \\
\hline & "How" culture & $\begin{array}{l}\text { Capability } \\
\text { alignment }\end{array}$ & Risk taker & $\begin{array}{c}\text { Technical and } \\
\text { financial support }\end{array}$ & Volunteerism & $\begin{array}{c}\text { Expansion } \\
\text { strategy }\end{array}$ \\
\hline
\end{tabular}




\begin{tabular}{|c|c|c|c|c|c|c|}
\hline Categories & $\begin{array}{c}\text { Sensing and } \\
\text { seizing } \\
\text { opportunity }\end{array}$ & $\begin{array}{c}\text { Structure and } \\
\text { Culture }\end{array}$ & $\begin{array}{c}\text { Leadership } \\
\text { and People } \\
\text { Skill }\end{array}$ & $\begin{array}{c}\text { Stakeholder } \\
\text { trust }\end{array}$ & $\begin{array}{c}\text { Social } \\
\text { engagement }\end{array}$ & Global Reach \\
\hline THEME/ & \multicolumn{3}{|c|}{ MANAGEMENT } & & MARKETING \\
GROUPING & \multicolumn{3}{|c|}{} & & \\
\hline
\end{tabular}

Third is the ability to seize and sense opportunities, innovative organization structure and culture, and people factor that include leadership and people skills. These are all essential for promoting the management innovation capabilities. The creation of "we culture" signifies for the togetherness of people within the social enterprise ecosystem; both for the people who create the values and receive the values. This is strengthened by the leaders who are risk takers, supported by the resiliency of the organization. Without the core support, it is difficult to create and sustain the social enterprise from the people, for the people.

Fourth, the marketing innovation is pillared by stakeholders' trust, social engagement and ability to reach the global market. Marketing capability is very important to get the future investment, financial and technical support, and involve in the incubator program for social enterprise start-ups. Supports from the society are needed to drive the community work. In this context, social awareness is essential. Hence establishing social awareness could be created by establishing the community compassion in order to get volunteerism and crowd-funding. In addition, social enterprise should reach a wider market too. Market tapping, partnership and strategic alliance and expansion strategy are the approach for global reach.

\section{Conclusion}

This study seek to understand what social enterprises in Malaysia aim to achieve for their social orientation of performance, objectives and impacts, and also to explore what are their innovation capabilities as the drivers for the achievements. Based on the qualitative study, we found social enterprise is in line with from the people to the people orientation. Improving the people quality of life is the main objective, other than the inspiration to allow the community to participate in the sharing economy. The achievements are driven by the capabilities to innovate their products/services, process, management and marketing efforts. A model is proposed that captures the integration of the innovation aspect.

As a conclusion, this model offers an opportunity for evaluation and validation trough other research design and setting. In essence, it could strengthen the basis of theoretical discussion as the model could be explained from the realms of structuration theory, social ecology theory and stakeholder theory. Practically, the study is significance mainly in providing the innovation strategies in boosting the social enterprise for achieving greater economic contribution. Besides, it could pave the way for future social financing models.

\section{Acknowledgements}

The authors gratefully acknowledge the help of Universiti Teknologi MARA in providing the Research Grant Scheme Fund (Project Number: 600-IRMI/MyRA 5/3/BESTARI (007/2017)) and Faculty of Business and Management for supporting the research work.

\section{References}

1. Bookchin, Murray (1974). Toward an ecological society._Philosophica_ 13 
2. Caroline, A. \& Antonio, L. (2011). Catalytic Innovation as a Strategy for Social Change and Economical Success. The Case of Mexico. Instituto Tecnológico Autónomo de México, Mexico.

3. Černe, M., Jaklič, M., \& Škerlavaj, M. (2013). Decoupling management and technological innovations: Resolving the individualism-collectivism controversy. Journal of International Management, 19(2), 103117.

4. Crossan, M. M., \& Apaydin, M. (2010). A multi-dimensional framework of organizational innovation: A systematic review of the literature. Journal of management studies, 47(6), 1154-1191.

5. Damanpour, F., \& Aravind, D. (2012). Managerial innovation: Conceptions, processes and antecedents. Management and organization review, 8(2), 423-454..

6. Defourny, Jacques, and C. Borzaga. From third sector to social enterprise. London: Routledge, 2001.

7. El Ebrashi, R. (2013). Social entrepreneurship theory and sustainable social impact. Social Responsibility Journal, 9(2), 188-209.

8. Elkington, J. (1998). Partnerships from cannibals with forks: The triple bottom line 21st-century business. Environmental Quality Management, 8(1), 37-51.

9. Gupta, S., Beninger, S., \& Ganesh, J. (2015). A hybrid approach to innovation by social enterprises: lessons from Africa. Social Enterprise Journal, 11(1), 89-112.

10. Hausmann, R. C. (2015). Organizing Ecosystems for Social Innovation: The Relationality of Contexts and Mechanisms in a Social Entrepreneurship Network (Doctoral dissertation, The George Washington University).

11. Hsu, Y. (2011). Design innovation and marketing strategy in successful product competition. Journal of Business \& Industrial Marketing, 26(4), 223-236.

12. Jajja, M. S. S., Kannan, V. R., Brah, S. A., \& Hassan, S. Z. (2017). Linkages between firm innovation strategy, suppliers, product innovation, and business performance: insights from resource dependence theory. International Journal of Operations \& Production Management, 37(8), 1054-1075.

13. Johannessen, J. A. (1997). Aspects of causal processes in social systems: Discussions of methodology. Kybernetes, 26(1), 30-51.

14. Kim, T. H., \& Moon, M. J. (2017). Using Social Enterprises for Social Policy in South Korea: Do Funding and Management Affect Social and Economic Performance? Public Administration and Development, 37(1), 15-27.

15. Liu, G., Eng, T. Y., \& Takeda, S. (2015). An investigation of marketing capabilities and social enterprise performance in the UK and Japan. Entrepreneurship Theory and Practice, 39(2), 267-298.

16. Milligan, K. (2013). Breaking the Binary: Policy Guide to Scaling Social Innovation. Cologny: Schwab Foundation for Social Entrepreneurship.

17. Ngonini, Xolani. "Mapping out the role of social entrepreneurship and innovation in economic growth and job creation: A case of a state-owned entity in South Africa." In European Conference on Management, Leadership \& Governance, p. 406. Academic Conferences International Limited, 2014.

18. Pisano, G. P. (2015). You need an innovation strategy. Harvard Business Review, 93(6), 44-54.

19. Robson, C. (2002). Real world research. 2nd. Edition. Blackwell Publishing. Malden.

20. Rousseau, M. B., Mathias, B. D., Madden, L. T., \& Crook, T. R. (2016). Innovation, firm performance, and appropriation: A meta-analysis. International Journal of Innovation Management, 20(03), 1650033.

21. Umberto, P., Lisa, L., \& Gerard, B. (2015). An overview of the concept of social innovation in the context of European initiatives and practices. European Sustainable Development Network.

22. Verhees, F. J., \& Meulenberg, M. T. (2004). Market orientation, innovativeness, product innovation, and performance in small firms. Journal of small business management, 42(2), 134-154.

23. Xolani, M. (2012). Mapping Out the Role of Social Entrepreneurship and Innovation in Economic Growth and Job Creation: A Case of a State-owned Entity in South Africa. Knowledge Management Division, Trans-Caledon Tunnel Authority, Centurion, South Africa.

24. Yin, R. K. (2003). Case study research: design and method (3rd). 